\title{
Prevalence of Gum Disease in Preterm and Term Adolescents
}

\author{
Sergio Spezzia ${ }^{1}$, Rosa Maria Eid Weiler ${ }^{2 *}$, Fernanda Malheiro Santos ${ }^{2}$, Liliana A. M. V. Takaoka ${ }^{1}$, \\ Stella M. C. P. A. C. Vieira ${ }^{1}$, Maria Sylvia De Souza Vitalle ${ }^{2}$ and Benjamin I. Kopelman ${ }^{1}$ \\ ${ }^{1}$ Department of Pediatrics, Neonatal Division of Medicine, Federal University of S. Paulo, Brazil \\ ${ }^{2}$ Department of Pediatrics, Adolescent Division of Medicine, Federal University of S. Paulo, Brazil
}

Received: February, 11, 2017; Accepted: February 18, 2017; Published: February 28, 2017

*Corresponding author: Rosa Maria Eid Weiler, Adolescent Division of Medicine, Department of Pediatrics, Federal University of S. Paulo,Rua Botucatu715, Vila Clementino, CEP 04023-062, São Paulo, SP, Brasil,Tel: 55-11 5299-9210;E- mail: Reid@Uol.Com.Br

\begin{abstract}
Aim: Assess and compare the prevalence of gum disease in preterm and term-born adolescents.

Materials and Methods: A cross section study was conducted involving adolescents between the ages of 10 and 19 . One group of 120 preterm-born adolescents and a g roup of 149 term-born adolescents (control). Physicians conducted physical exams in these groups to measure pubertal stages, dividing the patients into 3 subgroups according to Tanner's stages. The dental exam was conducted by four specialist dentist examiners. The community periodontal index of treatment need and measurements of plaque index were conducted.

Results: Comparing the preterm-born adolescents to the termborn ones, it was verified that the term group presented a higher prevalence of gum disease than the preterm group and the difference was statistically significant $(p<0.01)$. There was no statistically significant difference in the prevalence of gum disease when comparing the preterm-born adolescents with weight at birth $<1500$ to the ones weighing $\geq 1500$ grams. The preterm-born adolescent group did not present significant difference in the prevalence of gum disease in relation to Tanner's subgroups; however, when both groups were assessed together, it was verified that females, after the growth spurt, present a 3.7 times higher risk of gum disease.
\end{abstract}

Conclusion: The ranges of weight upon birth, low weight and very low weight did not impact the prevalence of gum disease in premature adolescents. Growth spurt increases the risk of developing periodontal disease in the female gender. Girls, after the spurt, tend to have more gum disease than girls before the spurt.

Key words: Gingivitis; Dental hygiene; Periodontal medicine; Women's Health; Puberty; Risk factor(s)

\section{Introduction}

The most common mouth diseases are dental caries and periodontal disease [1].

Among the factors leading to the appearance of periodontal disease, the most relevant are: the formation of the dental biofilm, systemic diseases, medications (contraceptives and antidepressants), bruxism, deficient nutrition, stress, smoking and hormonal changes that lead to gingivitis and exacerbate previous periodontal disease [2-5].

Periodontal disease is an infectious, chronic and asymptomatic disease, and both the gingivitis and the periodontitis forms are caused by exposure of the periodontal tissue to the action of bacteria that adhere to the dental surface [6].

Gingivitis is established when the gum tissue is inflamed. Gingivitis is defined as a pathological alteration of inflammatory characteristic of the gum tissues, with clinical appearance of bleeding, redness, sensitivity and edema, which is reversible, and may or may not progress to other areas of the tooth, thus resulting in loss of bone insertion (periodontitis). Gingivitis is manifested by bleeding on probing [7-9].

An aggravating factor of the periodontal diseases is the influence of hormones in the exacerbation of the periodontal inflammatory processes. The hormonal action favors the development of specific bacteria for the onset of the periodontal disease, and also changes the tissue metabolism regarding the inflammatory and immunological response [10]. Hormonal oscillations occur during adolescence and they are important events for the health of the mouth [6,11-16].

Chronic gingivitis is the most common periodontal infection among children and adolescents [17].

Several organic and hormonal alterations occur during puberty. Tanner's scale is used to evaluate pubertal stage. For males, this scale encompasses the evaluation of the genital development, starting with the growth of testis and scrotum, and soon after assessing the penis growth, and the proliferation of pubic hair (downiness, straight, thin, sparse hair to curly and pigmented hair with adult standards) that follow a scale from 1 to 5 (G1 to G5 and P1 to P5, respectively); for females it encompasses the evaluation of the development of breast and pubic hair (M1 to M5 and P1 to P5), Tanner's Scale of 1962, was used in this evaluation $[18,19]$.

According to the WHO [20] (1961) the concept of prematurity comprehends births with less than 37 weeks of gestation. 
Newborns (nbs) with gestational age between 34 and 36 weeks are called late premature and those born between 22 to 31 weeks and six days of pregnancy are considered extreme prematures [21,22].

A premature may have its growth modified due to the influence of several factors such as: gestational age and weight at birth among others [23]. It is known that the lower the weight at birth and the gestational age, the higher are the chances of morbidity [24,25].

Since birth, there are factors associated with prematurity that may affect the future development of a child in this situation. Several of those factors are also responsible for the impairment of oral health, for example, changes in the enamel formation of primary teeth [26]. Literature review showed that, so far, there is only one study that shows how the increase in morbidity among extreme premature affects gum health of adolescents. The study conducted by Rythen [27] et al., 2012, showed that in the group of examined patients, the prevalence of bacterial plaque and gingivitis and the occurrence of Streptococcus mutans were higher in the examined extreme-premature-born adolescents, when compared to the paired controls. Moreover, it was noted in this study that saliva secretion was lower in extreme premature children.

The aim of this paper was to assess and compare the prevalence of gum disease in preterm and term-born adolescents.

\section{Materials and Methods}

This is a descriptive and prospective cross-sectional study with convenience sample. A comparison was made between the groups of preterm and term-born adolescents and between the premature children born weighing less than 1500 grams with those weighing 1500 to 2500 grams.

A group of 269 adolescent patients was selected, with ages ranging from 10 to 19; 120 preterm-born adolescents were followed up at the Premature Outpatient Clinic of the Pediatrics Department of UNIFESP and 149 term-born adolescents (control group) were followed up at the outpatient clinic of the Adolescent Medicine Sector of the Pediatrics Department of UNIFESP.

The present clinical study was approved by the Ethics and Research Committee (CEP - acronym in Portuguese) of Paulista School of Medicine - The Federal University of São Paulo (UNIFESP), under opinion number 725.834 of July 23, 2014.

A sample calculation was made and used as a basis for the sample estimation for the Inquiry of Frias [28] et al., 2009, taking into consideration the prevalence of gum disease in the following groups: adolescents of 12 years of age and adolescents of 15 to 19 years of age, and considering a statistical strength of $80 \%$. Data were analyzed and significance was $p<0.05$. This calculation led to a sample amount corresponding to 157 subjects.

Patients excluded from the study were those who presented systemic diseases that could predispose to periodontal disease, such as diabetes, immunodeficiency, systemic lupus erythematosus; patients who smoked or were drug users and those who wore fixed orthodontic braces were also excluded.

Adolescents of both groups were previously evaluated by physicians at the Premature and Adolescent Medicine Outpatient Clinic regarding the Tanner's pubertal development stage, which is the evaluation the sexual maturation

The characteristics for girls is breasts of 1 to 5 (M1 to M5) and it refers to the levels of breast development. For boys, Tanner's pubertal stages evaluates testis, scrotum, and penis, also with stages 1 to 5 (G1 to G5).

Adolescents were classified in three subgroups [29,30], according to gender and Tanner's development stage. The pubertal spurt was taken into consideration for the analysis [31].

Subgroup 1 - Before pubertal spurt: Stages G1 and G2; M1.

Subgroup 2 - Period of pubertal spurt: Stages G3 and G4; M2, M3 and M4.

Subgroup 3 - After pubertal spurt: Stage G5; M5.

The clinical research was conducted by four examiners, who were trained, qualified, and tested dental surgeon regarding agreement of results. Patients were examined at the dental chair with the use of a reflector, dental mirror, and millimetric probe used by the WHO, \# 621 with a 0,5 mm spherical edge [32].

Bacterial plaque disclosing was performed using an Erythrosine-based solution in the vestibular, mesial, distal, lingual or palatal and occlusal or incisal surfaces of all the present teeth, in order to determine the 0' Leary [33] plaque index, which relates the number of stained surfaces by the total amount of surface, resulting in the total plaque index. This index receives a classification according to the following relation: \# of stain surfaces / \# of dental faces x 100.

The community periodontal index for treatment need (CPITN) of the patients was also analyzed [34-36]. This index establishes the periodontal condition based on gingival bleeding, and the presence of calculus and periodontal pocket. In order to prevent the exam of deeper grooves due to dental eruption, which could lead to a degree of confusion in the diagnosis of fake periodontal pockets, the examined index teeth for those younger than 20 years of age were the maxillary right and left permanent molar, mandibular right and left permanent molar, maxillary right central incisor and mandibular left central incisor [37]. For the same reasons, in individuals with less than 15 years of age the exam was limited to whether calculus and gum bleeding were present or not, and pockets were not assessed [34].

The CPITN scores are 0 (no periodontal problem), 1 (bleeding after probe), 2 (presence of calculus), 3 (pocket of 4 to $5 \mathrm{~mm}$ ) and 4 (pocket of $6 \mathrm{~mm}$ or more). This study did not show scores higher than 2 in individuals older than 15. For the other examined adolescents, younger than 15 , scores up to 2 were considered according to the recommendations for this index. The two groups were divided into two categories for comparison purposes: with gum health (score 0 ) and with gum disease (scores 1 and 2). 
Descriptive analysis was detailed in the statistical analysis used by means of absolute numbers and ratios for categorical data. Quantitative data was presented by average, standard deviation, mean and mode. Kappa index for categorical variables and interclass-correlation coefficient for continuous variables were used to verify agreement among examiners [38].

The Kolmogorov-Smirnov test was conducted to verify data normalcy. The chi-square test was used to compare the categorical variables and the $t$ Student test was used in independent samples to compare quantitative data. Verification of the association of Tanner sub-group, weight at birth $(<1500$ and $\geq 1500$ grams), premature born and term born babies with health and gum disease was done by means of analysis of univariate and multivariate logistic regression (adjusted for plaque index). Data were presented in Odds Ratio (OR) and Confidence Interval of 95\% (CI 95\%) [39].

Calculations were made by the Statistical Package for the Social Sciences (SPSS) software version 20.0 and the used significance level was $p<0.05$ [40].

\section{Results}

The total sample of participants in the research entailed 269 adolescents, being 133 (49.44\%) male and 136 (50.56\%) females. The sample was homogeneous regarding gender, as we did not find a significant difference between the two groups.

Regarding age, the average was significantly higher in the group of term adolescents, both for girls $(\mathrm{p}<0.001)$ and for both genders $(p<0.001)$. In the male group, the average age was also higher in the term group, however, it was not statistically significant $(p=0.056)$.

Plaque index was significantly higher in the group of term adolescents term $(p<0.05)$ for girls, boys, and both genders.

As to the distribution of adolescents in relation to Tanner sub-groups, the frequency was higher in individuals during spurt and after pubertal spurt for term adolescents and this difference was statistically significant $(p<0.012)$.

Table 1 shows the comparison between the prevalence of gum disease in the groups of preterm and term adolescents, both in the univariate and multivariate analysis (adjusted for plaque index). In both situations, gum disease was more prevalent in the term group, both for boys, girls and both genders. The difference was statistically significant in all cases. Preterm adolescents presented lower prevalence (46.7\%) when compared to term adolescents (76.9\%).

There was no significant difference in the prevalence of gum disease between the groups of preterm adolescents with weight at birth $<1500 \mathrm{~g}$ and $\geq 1500 \mathrm{~g}$, both for boys ( $p=0.302$ ), girls ( $\mathrm{p}=$ $0.256)$ and both genders ( $p=0.134)$.

Table 2 shows that there was no significant association between the Tanner subgroups (before spurt - 1, at spurt - 2 and after spurt - 3) with gum disease, for the male, female and both gender groups for the univariate and multivariate analysis (adjusted for plaque index).

Nevertheless, Table 3, with the preterm and term adolescent groups together, shows that females after spurt (subgroup 3) present a 3.5 higher risk (in the univariate analysis) and 3.7 higher risk (in the multivariate analysis) of gum disease than before and after spurt. It is noteworthy that, even though the $\mathrm{p}$ value was not statistically significant, the result becomes significant because the confidence interval did not go over value 1. The other subgroups did not show a statistically significant difference in the prevalence of gum disease.

Both the kappa index as the intraclass correlation coefficient have the same objective, that is, verify the result agreement among the four examiners; however, kappa is for categorical data (CPITN) and the intraclass correlation coefficient is for continuous data (plaque index). The kappa test result was 0.802 , showing a very good agreement among the examiners for the CPITN. The intraclass correlation coefficient was used for plaque index. The result was 0.956 also considered as very good.

\section{Discussion}

Taking into account the age of the preterm and term adolescents in the sample distribution we verified that the average age is higher in the term group, considering the male, female, and both gender groups together, and in the female and both gender groups the average was higher and statistically significant $(p<0.001)$.

This fact is relevant because it is known that the increase in age increases the risk of periodontal diseasel [41]; however, we should be cautious and avoid crediting the obtained results only to the age factor, since the plaque index, which shows the level of hygiene, presented a higher average in males, females, and both genders together in the group of term adolescents, and the differences were statistically significant. That is, the term adolescents of this sample were older and showed poorer buccal hygiene.

Both groups of the sample were homogeneous in the distribution regarding male and female genders; nevertheless, regarding pubertal stages or Tanner subgroups, the group of term adolescents showed a higher frequency of individuals at spurt and after pubertal spurt than the group of preterm adolescents and this difference was statistically significant. This fact is also relevant because Mombelli [42] et al., (1989), followed up 42 adolescents between the ages of 11 and 15 in a 4-year longitudinal study and evaluated their gum status, bone age, and Tanner stages during this period. They found that, both boys and girls presented a significant increase in gum bleeding in the beginning of the pubertal spurt, and in $35 \%$ of the cases, this trend of gum bleeding reached a peak 1 to 5 years after the beginning of puberty. Therefore, the fact that the sample of preterm adolescents show a higher frequency of individuals in more advanced pubertal stages may have also influenced the obtained results taking into account the total sample, both for 
males and females. This shows the importance of the prevention of periodontal disease in this phase, as it is still a reversible situation. However, with no intervention, it could progress to periodontitis and could compromise the supporting tissue, lead to bone loss, and become irreversible.

The analysis of univariate and multivariate logistic regression (adjusted for plaque index) was used for the comparison of prevalence of gum disease in the preterm and term adolescent groups, in the three categories: males, females and both genders together. The term adolescents presented a higher prevalence of gum disease, and this happened both in the univariate and the multivariate analysis, and the differences were statistically significant $(p<0.001)$ (Table 1$)$. As the multivariate logistic regression analysis is adjusted for the plaque index, it removes a possible bias in the results, since this is the primary factor in the establishment of gum disease [43].

Gum disease is multifactorial, and several factors can explain those results. It is essential to understand those factors to avoid wrongly concluding that being a premature is a protective factor against gum disease. The preterm adolescent groups are cared at the Premature Outpatient Clinic and receive a close followup starting at birth. This explains why the plaque index in this group is significantly lower than that of the term adolescents. Lower plaque indexes show the result of such prevention. On the other hand, term adolescents were assessed before joining an odontological prevention program.

Moreover, as gum disease is multifactorial, other facts reinforce these results: the term adolescent group is much older and more advanced in the pubertal development, and this increase the risk of gum disease, as previously discussed.

When analyzing the preterm adolescent group in regard to plaque index, it was verified that there was no significant difference between the group that was born weighing $<1500$ or $\geq 1500$ grams, both for males, female, and both genders together. Upon conducting the logistic regression analysis to compare preterm adolescents with weigh at birth $<1500$ or $\geq 1500$ grams regarding prevalence of gum disease, no statistically significant difference was found in none of the analyses (univariate and multivariate) and in none of the categories (males, females, and both genders together). That may suggest that a well-conducted prevention might overcome the possible risk factors related to extreme prematurity.

A study conducted by Rythén [27] et al., (2012), assessed extremely-premature born adolescents and compared them to term-born adolescents, evaluating several parameters of mouth health. They found a higher prevalence of plaque index, gingivitis and oral colonization by Streptococcus mutans in the extremelypremature born adolescents as compared to the group of term adolescents. The Tanner pubertal stages were not assessed in this study.

Tables 2 and 3 present gum disease with Tanner's subgroups for the sample of preterm adolescents (Table 2) with the total sample (Table 3). Univariate and multivariate logistic regression was used for the analysis and, in the first case, (Table 2) no association was detected; nevertheless, when the total sample was used, there was a significant relation in the Tanner's subgroup 3, that is, after spurt in females. The results obtained showed that girls after spurt present a 3.7 higher chance of having gum disease, when compared to girls before spurt. This result occurred in the multivariate analysis adjusted for the plaque index and, therefore, removes the bias of that variable.

Table 1: Association between gum disease with the preterm and term adolescent group.

\begin{tabular}{|c|c|c|c|c|}
\hline & \multicolumn{2}{|c|}{$\begin{array}{l}\text { Gum disease } \\
\text { (Univariate analysis) }\end{array}$} & \multicolumn{2}{|c|}{$\begin{array}{l}\text { Gum disease } \\
\text { (Multivariate analysis)* }\end{array}$} \\
\hline & OR (IC 95\%) & $\mathrm{p}$ value & OR (IC 95\%) & $\mathrm{p}$ value \\
\hline & \multicolumn{4}{|c|}{ Males } \\
\hline Preterm & 1 & $<0,001$ & 1 & $<0.001$ \\
\hline \multirow[t]{2}{*}{ Term } & $\begin{array}{c}6.88(2.92- \\
16.12)\end{array}$ & & $\begin{array}{c}6.06(2.53- \\
14.48)\end{array}$ & \\
\hline & \multicolumn{4}{|c|}{ Females } \\
\hline Preterm & 1 & $<0.001$ & 1 & $<0.001$ \\
\hline \multirow[t]{2}{*}{ Term } & $\begin{array}{c}4.00(2.09- \\
9.22)\end{array}$ & & $\begin{array}{c}3.99(1.87- \\
8.52)\end{array}$ & \\
\hline & \multicolumn{4}{|c|}{ Both genders } \\
\hline Preterm & 1 & $<0.001$ & 1 & $<0,001$ \\
\hline Term & $\begin{array}{c}5, .6(2.98- \\
8.95)\end{array}$ & & $\begin{array}{l}4.58(2.62- \\
8,02)\end{array}$ & \\
\hline
\end{tabular}

- Logistic regression adjusted for plaque index; $p<0.05$. OR: odds ratio; IC 95\%: 95\% confidence interval

Table 2: Association between Tanner subgroup with gum disease in preterm adolescents.

\begin{tabular}{|l|c|c|c|c|}
\hline & \multicolumn{2}{|c|}{$\begin{array}{c}\text { Gum disease } \\
\text { (Univariate analysis) }\end{array}$} & \multicolumn{2}{c|}{$\begin{array}{c}\text { Gum disease } \\
\text { (Multivariate analysis)* }\end{array}$} \\
\hline & OR (IC 95\%) & p value & OR (IC 95\%) & p value \\
\hline & \multicolumn{3}{|c|}{ Males } \\
\hline
\end{tabular}

\begin{tabular}{|c|c|c|c|c|}
\hline Subgroup 1 & 1 & 0.482 & 1 & 0.425 \\
\hline Subgroup 2 & $0,92(0,28-$ & & $0,77(0,22-$ & \\
& $3,03)$ & & $2,70)$ & \\
\hline \multirow{2}{*}{ Subgroup 3 } & $0,45(0,12-$ & & $0,40(0,10-$ & \\
& $1,68)$ & & $1,57)$ & \\
\hline
\end{tabular}

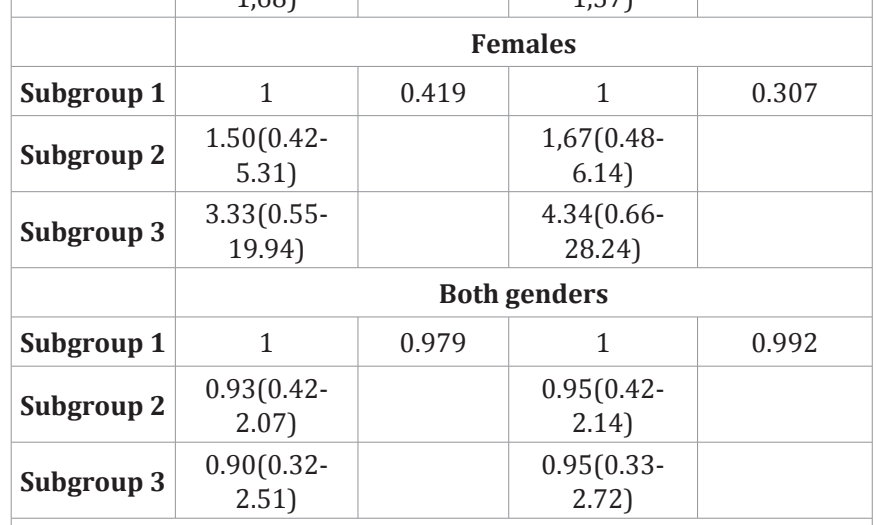

* Logistic regression adjusted for plaque index; $p<0.05$. OR: odds ratio; IC 95\%: 95\% confidence interval 
Table 3: Association between Tanner subgroups and gum disease (complete sample).

\begin{tabular}{|c|c|c|c|c|}
\hline & \multicolumn{2}{|c|}{$\begin{array}{c}\text { Gum disease } \\
\text { (Univariate analysis) }\end{array}$} & \multicolumn{2}{|c|}{$\begin{array}{c}\text { Gum disease } \\
\text { (Multivariate analysis)* }\end{array}$} \\
\hline & OR (IC 95\%) & $\mathrm{p}$ value & OR (IC 95\%) & $\mathrm{p}$ value \\
\hline \multicolumn{5}{|c|}{ Males } \\
\hline Subgroup 1 & 1 & 0,919 & 1 & 0.966 \\
\hline Subgroup 2 & $\begin{array}{l}1,19(0.50- \\
2.83)\end{array}$ & & $\begin{array}{l}1.09(0,45- \\
2.65)\end{array}$ & \\
\hline Subgroup 3 & $\begin{array}{l}1.08(0.41- \\
2.80)\end{array}$ & & $\begin{array}{l}1.11(0.42- \\
2.92)\end{array}$ & \\
\hline \multicolumn{5}{|c|}{ Female } \\
\hline Subgroup 1 & 1 & 0.103 & 1 & 0.100 \\
\hline Subgroup 2 & $\begin{array}{c}1.97(0.73- \\
5.290)\end{array}$ & & $2,21(0.79-6.13)$ & \\
\hline Subgroup 3 & $\begin{array}{c}3.53(1.10- \\
11.28)^{*}\end{array}$ & & $\begin{array}{c}3.71(1.11- \\
12.35)^{*}\end{array}$ & \\
\hline \multicolumn{5}{|c|}{ Both genders } \\
\hline Subgroup 1 & 1 & 0.448 & 1 & 0.408 \\
\hline Subgroup 2 & $\begin{array}{c}1.13(0.63- \\
2.02)\end{array}$ & & $\begin{array}{c}1.17(0,64- \\
2.15)\end{array}$ & \\
\hline Subgroup 3 & $\begin{array}{c}1.56(0.77- \\
3.17)\end{array}$ & & $\begin{array}{c}1.63(0,79- \\
3.37)\end{array}$ & \\
\hline $\begin{array}{l}\text { * Logistic reg } \\
\text { IC 95\%: 95\% } \\
\text { Significant (IC }\end{array}$ & $\begin{array}{l}\text { ession adjusted } \\
\text { onfidence inte } \\
\text { does not go by }\end{array}$ & r plaqu & dex; $p<0.05$ & : odds ratio \\
\hline
\end{tabular}

This result is in accordance with literature studies such as the Mombelli [42] et al., (1989) study, that found a significant increase in bleeding after the pubertal spurt, both in boys and in girls.

Delaney [44] et al., (1986), found significant changes in the gingival microbiota components associated to bone, sexual, and chronological age, before, during, and after spurt, thus favoring the prevalence of periodontal disease with the increase seen in in all evaluated ages. According to the reviews of Bimstein \& Matsson [45], (1999), and Spezzia [16], (2016), the influence of female sexual hormones in the gingival tissues and the plaque composition are very relevant during puberty in relation to the increase of periodontal disease risk.

Therefore, based on literature, we can suggest that the higher risk of girls presenting gum disease after spurt is related to the higher amount of circulating sexual hormones.

We should remember that, according Tanner's stages, the increase in the amount of female sexual hormones advance until adult age, and this happens for both boys and girls, although in different magnitude [46]. The study of Mombelli [42] et al., (1989), managed to find an increase in gingival bleeding, both in boys and in girls, and the increase followed Tanner's stages. This was likely possible due to the fact that it is a longitudinal study that used an index that allows to verify the inflammation degrees, the same not being true for CPITN index. The use of CPITN index is favorable because it is a simple, fast, and easy-to-carry out method, with international uniformity $[36,47]$; however, its limitation is not detecting the nuances in the inflammation levels.

We could mention as limiting factors of the study the fact that there was no sample pairing for age and Tanner's stages, which established bias and limitation to the CPITN index; despite that, when evaluating a sample with a higher number of individuals, the study was effective in detecting a higher prevalence of the disease in the more advanced pubertal stages in girls.

Literature is quite sparse in studies relating gum disease to Tanner stages. Besides the study of Mombelli [42] et al., (1989), which evaluated gum bleeding, there is the study of Delaney [44] et al., (1986), which verifies the changes in the gingival microbiota with the development of the pubertal stages. Both related the gingival status in adolescents to Tanner pubertal stages. A crosssectional study was conducted by Spezzia [48] et al., (2016), and the objective was to evaluate the existence of a relation between gum disease in adolescents and Tanner's stages (before, during and after spurt). No statistically significant difference was found in this study, even though the sample was smaller than that of the current study.

The importance of the present study is the fact that it managed to verify in an epidemiologic way what has been long considered as biological plausibility: female hormones during puberty increased the risk of periodontal disease. A survey conducted showed that, regarding the study with preterm-born adolescents and Tanner's stages related to gum disease, our study was pioneer in the literature. On the other hand, the fact that we have negated the hypothesis that there would be a higher prevalence of gum disease in preterm adolescents, shows that a well-done prevention minimizes possible risks.

Both the literature and our data showed that gum disease prevalence is high during adolescence. The evaluated group, which had not yet joined the prevention program (group of term adolescents), presented the value of $76.9 \%$; the group that had a follow-up with a prevention program from early age (group of preterm adolescents) presented a value of $46.7 \%$. Therefore, prevention of gum disease during the adolescence is imperative.

\section{Conclusions}

Weight ranges at birth, low weight, and very low weight did not influence the prevalence of gum disease in premature adolescents.

Spurt increases the risk of developing periodontal disease in females. Girls, after spurt tend to present more gum disease than girls before spurt.

\section{Ethical Approval}

The experimental procedures were approved by the institution of animal care and ethical committee of the Paulista School of Medicine, Federal University of S. Paulo. Brazil (Code 725.834 of July 23, 2014 ), and performed in full accordance with the World Medical Association Declaration of Helsinki. 


\section{Author's Contributions}

Article writing (Sergio Spezzia), Supervisor of the study, design and and approval of the version to be published- point of view of Neonatal Pediatrics (Benjamin I Kopelman), Cosupervisor of the study, design and approval of the version to be published- point of view of Adolescent Medicine (Rosa Maria Eid Weiler), examiners who conducted clinical research (Sergio Spezzia, Fernanda M. Santos, Liliana A.M.V. Takaoka and Stella M.C.P.A.C. Vieira), examiners who conducted Tanner's evaluation of the adolescents in the sample (Maria Sylvia de Souza VitalleAdolescent Medicine)

\section{References}

1. WHO. Oral health, 2007. Disponível em: Acessado em 19 de março de 2014.

2. Beck JD. Periodontal implications: older adults. Ann Periodontol. 1996;1(1):322-357. doi:10.1902/annals.1996.1.1.322

3. Grodstein F, Colditz GA, Stampfer MJ. Tooth loss and hormone use in postmenopausal women. Compend Contin Educ Dent Suppl. 1998;(22):S9-16

4. Jeffcoat MK, Lewis CE, Reddy MS, Wang CY, Redford M.Post-menopausal bone loss and its relationship to oral bone loss. Periodontol. 2000;23(1):94-102. doi: 10.1034/j.1600-0757.2000.2230109.x

5. Leite A, Conti R. O Tabagismo e a Boca. Rev Assoc Paul Cir Dent 2001;55:7-14.

6. Axelsson P, Lindhe J. Effect of controlled oral hygiene procedures on caries and periodontal disease in adults. Results after 6 years. J Clin Periodontol. 1981;8(3):239-248

7. Beck JD, Pankow J, Tyroler HA, Offenbacher S. Dental infections and atherosclerosis. Am Heart J. 1999;138(5):S528-S533. doi org/10.1016/S0002-8703(99)70293-0

8. Engebretson SP, Lalla E, Lamster IB. Periodontitis and systemic disease. NY State Dent J. 1999;65(8):30-32.

9. Newman MG, Takei HH, Klokkevold PR, Carranza FA. Periodontia Clínica. 11aed. Rio de Janeiro: Elsevier. 2011;p. 1328.

10. Silva SR. Atendimento à Gestante: nove meses de espera? Rev Assoc Paul Cir Dent. 2002;56:89-99.

11. Lascala NT, Moussalli NH. Alteracoes Hormonais. Periodontia Clínica - Especialidades Afins. 5a. Ed., Artes Medicas: Sao Paulo; 1985; p. 24853.

12. Lindhe J. Tratado de Periodontologia Clínica. Guanabara Koogan: Rio de Janeiro. 1992;206-214.

13. Lascala NT, Moussalli NH. Diagnostico Diferencial em Periodontia. In: Compendio Terapeutico Periodontal. Artes Medicas: Sao Paulo. 1994 p. 59-92.

14. Harari S. Pratica de Promocao de Saude no Binomio Materno-infantil. In: Odontologia Integrada: atualizacao para o clinico e o especialista. Rio de Janeiro: Pedro Primeiro. p. 25-55, 2002.

15. Hey-Hadavi JH. Women's oral health issues: sex differences and clinical implications. Women's Health Prim Care. 2002; 5(3):189-99.

16.Spezzia S. Inter-relação entre Hormônios Sexuais e Doenças Periodontais nas Mulheres. Braz J Periodontol. 2016; 26(2):40-7.
17. Oh TJ, Eber R, Wang HL. Periodontal diseases in the child and adolescent. J Clin Periodontol. 2002;29(5):400-410. doi: 10.1034/j.1600-051X.2002.290504.x

18. Tanner JM. Growth at adolescence. 2 a . Ed. Oxford: Blackwell; 1962.

19. Vitalle MSS, Medeiros EHGR. Adolescência uma Abordagem Ambulatorial. Guia de Medicina Ambulatorial e Hospitalar / UNIFESP - EPM. 1ª. Ed. Barueri: Ed. Manole. 2008.

20. Organizaçao Mundial da Saude, Public health aspects of low birth weight, technical report series, v. 217, Genebra. 1961.

21. Silveira MF, Santos IS, Barros AJ, Matijasevich A, Barros FC, Victora CG. Aumento da Prematuridade no Brasil: revisão de estudos de base populacional. Rev Saúde Pública. 2008;42(5):957-964.

22. Ministerio da Saude. Manual de Vigilancia do Obito Infantil e Fetal e do Comite de Prevencao do Obito Infantil e Fetal. Brasília - DF, abril de 2009. 77 p. Disponível em: http://www.saude.gov.br/ Acessado em 27 de agosto de 2014 .

23. Saigal S, Stoskopf BL, Streiner DL, Burrows E. Physical growth and current health status of infants who were of extremely low birth weight and controls at adolescence. Pediatrics. 2001;108(2):407-415.

24. Aarnoudse-Moens CS, Weisglas-Kuperus N, van Goudoever JB, Oosterlaan J. Meta-analysis of neurobehavioral outcomes in very preterm and/or very low birth weight children. Pediatrics. 2009;124(2):717-728.

25. De Kieviet JF, Piek JP, Aarnoudse-Moens CS, Oosterlaan J. Motor development in very preterm and very low-birth-weight children from birth to adolescence: a meta-analysis. JAMA. 2009;302(20):22352242. doi: 10.1001/jama.2009.1708

26. Takaoka LA, Goulart AL, Kopelman BI, Weiler RM. Enamel defects in the complete primary dentition of children born at term and preterm. Pediatr Dent. 2011;33(2):171-176.

27. Rythen M, Niklasson A, Hellstrom A, Hakeberg M, Robertson A. Risk indicators for poor oral health in adolescents born extremely preterm. Swed Dent J. 2012;36(3):115-124.

28. Frias AC, Marques RAA, Teixeira DSC, Soares MC. Levantamento Epidemiológico em Saúde Bucal. Cidade de São Paulo 20082009. Resumo da primeira fase: crianças e adolescentes. Disponívelem:http://www.prefeitura.sp.gov.br/cidade/secretarias/ upload/saude/arquivos/saudebucal/LESB_Resumo_primeirafase.pdf Acessado em 11 de abril de 2014

29. Weiler RM, Vitalle MS, Mori M, Kulik MA, Ide L, Pardini SR et al. Prevalence of signs and symptoms of temporomandibular dysfunction in male adolescent athletes and non-athletes. Int Pediatr Otorhinolaryngol. 2010;74(8):896-900. doi: 10.1016/j. ijporl.2010.05.007

30. Weiler RM, Santos FM, Kulic MA, de Souza Lima MP, Pardini SR, Mori $\mathrm{M}$ et al. Prevalence of signs and symptoms of temporomandibular dysfunction in female adolescent athletes and non-athletes. Int J Pediatr Otorhinolaryngol. 2013;77(4):519-524. doi: 10.1016/j. ijporl.2012.12.024

31. Saito MI. Aceleracao e Desaceleracao do Crescimento. In: Coates V, Francoso LA, Beznos GW. Medicina do adolescente. Savier: Sao Paulo. 1993.

32.WHO. Epidemiology, etiology and prevention of periodontal diseases. Thechn Rep Ser, No. 621, World Health Organization, Geneva, Switzerland. 1978. 
33. 0 Leary TJ, Drake RB, Naylor JE. The plaque control record. J Periodontol. 1972;43(1):38. doi: 10.1902/jop.1972.43.1.38

34. Ainamo J, Barmes D, Beagrie G, Cutress T, Martin J, Sardo-Infirri J. Development of the Wold Health Organization (WHO) community periodontal index of treatment needs (CPITN). Int Dent J. 1982;32(3):281-291.

35. Cutress TW, Ainamo I, Sardo-infirri J. The community periodontal index of treatment needs (CPITN) procedure for population groups and individuals. Int Dent J. 1987;37(4):222-233.

36. Vassao SAS. Estagio Atual da Aplicaçao do CPITN. [Monografia]. Especializaçao em Periodontia. Piracicaba: Faculdade de Odontologia de Piracicaba - Universidade Estadual de Campinas. 1994.

37. Miyazaki H, Pilot T, Lederq M. Periodontal profiles: an overview of CPITN data in the WHO global oral data bank for the age groups 15-19 years, 35-44 years. Geneva, World Health Organization.1990.

38. Landis JR, Koch GG. The measurement of observer agreements for categorical data. Biometrics. 1977;33(1):159-174. doi: $10.2307 / 2529310$

39. Field A. Descobrindo a Estatística usando o SPSS. $2^{\text {a }}$ ed. Porto Alegre: Artmed. 2009.

40. Norusis MJ. SPSS for Windows: Advanced Statistics, release 6.0. Chicago, IL: SPSS Inc. 1993.

41. Petersen PE, Ogawa H. Strengthening the prevention of periodontal disease: the WHO approach. J Periodontol. 2005;76(12):2187-2193. doi:10.1902/jop.2005.76.12.2187

42. Mombelli A, Gusberti FA, van Oosten MA, Lang NP. Gingival health and gingivitis development during puberty. A 4-year longitudinal study. J Clin Periodontol. 1989;16(7):451-456. doi: 10.1111/j.1600051X.1989.tb01674.x

43. Marsh PD. Dental Plaque as a microbial biofilm. Caries Res. 2004;38(3):204-211. doi:10.1159/000077756

44. Delaney JE, Ratzan SK, Kornman KS. Subgingival microbiota associated with puberty: studies of pre -, circum -, and post-pubertal human females. Pediatr Dent. 1986;8(4):268 -275.

45. Bimstein E, Matsson L. Growth and development considerations in the diagnosis of gingivitis and periodontitis in children. Update Pediatr Dent. 1999;21(3):186-191.

46. Plauchu H, Claustrat B, Betena B, David M, François R. Le test a lormone hypothalamique synthetique LHRH chez l'enfant normal de la naissance a lage adulte. Pediatric. 1980; 35:119-31.

47. Brasil. Ministério da Saúde. Projeto SB 2000: condições de saúde bucal da população brasileira no ano 2000. Manual do examinador. Série C. Projetos, Programas e Relatórios.n. 53, 2001, 49 ps.

48. Spezzia S, Weiler RME, Santos FM, Lima MPCS, Vitalle MSS. Gingival disease in adolescents related to puberal stages and nutritional status. Braz J Surg Clin Res. 2016;15(2):11-16. 